\title{
Nuorten liike-elämän ammattilaisten työidentiteetit rakentuvat vuorovaikutuksessa
}

\author{
Kirsi-Marja Toivanen
}

\begin{abstract}
Viittausohje:
Toivanen, K-M. (2021). Nuorten liike-elämän ammattilaisten työidentiteetit rakentuvat vuorovaikutuksessa. Prologi - Viestinnän ja vuorovaikutuksen tieteellinen aikakauslehti, 17(1), 36-40.

https://doi.org/10.33352/prlg.103235

To cite this article:

Toivanen, K-M. (2021). Nuorten liike-elämän ammattilaisten työidentiteetit rakentuvat vuorovaikutuksessa [The work identities of young business professionals are constructed in interaction]. Prologi - Journal of Communication and Social Interaction, 17(1), 36-40. https://doi.org/10.33352/prlg.103235
\end{abstract}

Prologi

- Viestinnän ja vuorovaikutuksen tieteellinen aikakauslehti journal.fi/prologi/

ruotsiksi: Prologi - Tidskrift för Kommunikation och Social Interaktion englanniksi: Prologi - Journal of Communication and Social Interaction Julkaisija: Prologos ry.

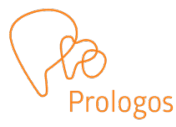

Avoin julkaisu / Open Access ISSN 2342-3684 / verkko ISSN 1795-7613 / painettu versio 


\title{
Lectio Praecursoria
}

Prologi, 17(1)

$36-40$

https://doi.org/10.33352/prlg.103235

\section{(i) (2)}

\section{Nuorten liike-elämän ammattilaisten}

\section{työidentiteetit rakentuvat vuorovaikutuksessa}

\author{
Kirsi-Marja Toivanen \\ FT, Yliopettaja \\ Karelia-ammattikorkeakoulu \\ kirsi.toivanen@karelia.fi
}

vastaanotettu 11.3. / hyväksytty 29.3. / julkaistu 5.5.2021

ASIASANAT: diskurssi, kansainvälinen liiketoiminta, keskinäisviestintä, positiointi, työidentiteetti

Lectio praecursoria viestinnän väitöskirjaksi tarkoitetun tutkimuksen Multiple Identities at Work Discursive Construction of Work Identity of Young Business Professionals -tarkastustilaisuudessa Jyväskylän yliopistossa 6.2.2021. Vastaväittäjänä toimi apulaisprofessori Heidi Hirsto (Vaasan yliopisto) ja kustoksena professori Anu Sivunen (Jyväskylän yliopisto). Työn pääohjaajana toimi apulaisprofessori Leena Mikkola (Tampereen yliopisto).

Väitöskirja on luettavissa verkossa osoitteessa http://urn.fi/URN:ISBN:978-951-39-8520-2

\section{Tutkimuksen taustaa ja tavoitteita}

Muuttuva työelämä tai niin sanottu työn murros on herättänyt vilkasta keskustelua yhteiskunnallisesti jo useiden vuosien ajan. Monilla tahoilla on pyritty ennakoimaan, mitä tulevaisuuden työ on ja mitä se tarkoittaa osaamisen, työn sisältöjen, työn tekemisen käytänteiden ja paikkojen tai organisointitapojen näkökulmista. Kuluneen vuoden aikana koronapandemia on arkipäiväistänyt tätä keskustelua ja tuonut meneillään olevan muutoksen konkreettisella tavalla näkyväksi, kun työ on siirtynyt Teams-kokouksiin ja ruokapöytien ääreen. Laajoista, globaalisti työtä koskettavista tulevaisuusvisioista on laskeuduttu pohtimaan myös sitä, millä tavoin muutos vaikuttaa työyhteisöihin, työhön liittyviin ja työn ulkopuolisiin vuorovaikutussuhteisiin tai työntekijöihin heidän työhön liittyvän, ammatillisen identiteettinsä kannalta, siis teemoihin, joista myös viestinnän ja vuorovaikutuksen tutkimus on kiinnostunut. 
Tutkimukseni kiinnittyy työntutkimuksen, interpersonaalisen viestinnän ja diskurssintutkimuksen kenttiin ja sitä on ohjannut sekä tieteellinen että käytännöllinen tarve. Tutkimuksessani olen pyrkinyt ymmärtämään työhön liittyvän identiteetin diskursiivista rakentumista kansainvälisen liike-elämän nopeasti muuttuvissa konteksteissa. Identiteetti on kompleksinen, dynaaminen ja kiistanalainenkin käsite, jota voidaan tarkastella useista lähtökohdista käsin. Sosiaalinen konstruktionismi näkee identiteetit joustavina ja sosiaalisessa vuorovaikutuksessa muuttuvina. Diskurssintutkimuksen jatkumolla tutkimukseni edustaa ensisijaisesti sen analyyttistä ja tulkitsevaa suuntausta. Tutkimuksen keskiössä ovat olleet mikrotason diskurssit eli työpaikan arkinen vuorovaikutus ja nuorten ammattilaisten tuottamat narratiivit, joissa rakentuvaa relationaalista työidentiteettiä tutkin sekä havainnoimalla että etnografisilla, keskustelunomaisilla haastatteluilla. Identiteettien rakentuminen keskinäisviestinnässä ei kuitenkaan tapahdu irrallaan vaan heijastelee ja osaltaan myös rakentaa organisatorisia ja laajempia sosiokulttuurisia diskursseja ja merkityksiä.

Monografiamuotoisen väitöskirjani ensimmäisessä tutkimuskysymyksessä kysyin, mitä liike-elämässä toimivien nuorten ammattilaisten identiteetin ulottuvuuksia ja merkityksiä tuotetaan diskursiivisesti kansainvälisen työn kontekstissa. Olen pyrkinyt sekä kuvailemaan että tulkitsemaan ja ymmärtämään näitä diskursiivisesti tuotettuja merkityksiä. Toisen tutkimuskysymyksen avulla etsin niitä viestinnällisiä käytänteitä ja vuorovaikutuksen tapoja, joilla identiteettejä rakennetaan ja positioidaan työhön liittyvässä vuorovaikutuksessa.

Aineistolähtöisen väitöstutkimukseni käytännöllisenä tavoitteena on ollut tarkastella identiteettityön, kieli- ja viestintäosaamisen ja koulutuksen kytköksiä opetussuunnitelmien kehittämiseksi. Tutkimustani on motivoinut oma työni ammattikorkeakoulun International Business -koulutuksessa. Opiskelijajoukon entisestään monimuotoistuessa olen joutunut pohtimaan sitä, millaisia viestintä- ja vuorovaikutustaitoja kansainvälinen liiketoiminta, alan asiantuntijuus ja erilaisissa tehtävissä toimiminen ja niissä kehittyminen edellyttävät. Erityisesti kysymys kulttuurienvälisen viestinnän merkityksestä ja sisällöistä globaalissa ja monimuotoisessa työelämässä oli se, joka johdatti minut viestintätieteiden jatko-opintoihin. Tuolloinen viestintätieteen laitos ehdotti kuitenkin pääaineekseni puheviestintää, mikä johti minut hetkeksi akateemisammatilliseen identiteettikriisiin. Miten puheviestintä liittyy siihen, mistä olen työssäni kiinnostunut ja mitä haluan selvittää? Kysymykseni ei ollut tuolloin retorinen. Nyt jälkeenpäin tiedän, etten varmaankaan olisi kyseenalaistanut käsityksiäni, ellei minua olisi haastettu astumaan mukavuusalueeni ulkopuolelle tutkimaan kulttuurienvälistä, ammatillista viestintää nimenomaan interpersonaalisen vuorovaikutuksen ja vuorovaikutussuhteissa rakentuvan työidentiteetin kautta.

\section{Tutkimukseen osallistuneet nuoret ammattilaiset}

Harkinnanvaraisella otannalla pyrin tutkimuksessani mahdollisimman heterogeeniseen, joskin rajattuun osallistujajoukkoon. Keväällä 2016 havainnoin ja haastattelin kuutta Suomessa BBA-tutkinnon suorittanutta nuorta ammattilaista heidän toimistotyöpäivänsä aikana. Kolme ja puoli vuotta kestävään englanninkieliseen BBA-tutkinto-ohjelmaan hakeutuu opiskelijoita useista maista. Tutkinto ei itsessään pätevöitä tiettyyn pääteammattiin vaan mahdollistaa hakeutumisen monenlaisiin työtehtäviin globaaleilla työmarkkinoilla. Osallistujat olivat toimineet työelämässä vähintään 
kaksi vuotta valmistumisensa jälkeen. Työnantajayritykset vaihtelivat pienistä mikroyrityksistä suuriin globaaleihin teknologiayrityksiin. Neljä osallistujista työskenteli kansainvälisissä myyntitehtävissä, yhden henkilön työ liittyi ostotoimintaan ja kuudennen osallistujan työtehtävien kirjo sisälsi muun muassa verkkosivujen ylläpitoa ja toimimista useissa päällekkäisissäkin projekteissa. Osallistujien taustat ja elämäntilanne poikkesivat myös monilta muilta osin toisistaan. Aineisto koostuu siis erilaisista tapauksista, joita on käsitelty osittain erikseen. Toisaalta ne myös yhdessä muodostavat aineistokokonaisuuden, jonka avulla on ollut mahdollista saada laajempi näkemys nuorten ammattilaisten identiteettityöstä kansainvälisessä yrityselämässä.

\section{Aineiston analyysi}

Metodologiset valintani ovat yhdistelmä kulttuurista diskurssianalyysiä ja positiointiteoriaan perustuvaa positiointianalyysiä. Kulttuurinen diskurssianalyysi lähestyy merkitysten rakentumista viiden analyysityökalun, niin sanottujen merkityskeskittymien avulla. Tähän tutkimukseen valittiin näistä kolme: ihmisenä oleminen, esimerkiksi identiteettiin, persoonaan ja kasvoihin liittyvät ilmaisut ja kielimuodot; toimiminen suhteessa toisiin ihmisiin ja instituutioihin; ja toiminnan ja tekojen, mukaan lukien puhe- ja vuorovaikutustekojen, järjestyneisyys. Näiden keskeisten merkityskeskittymien lisäksi analyysiin sisällytettiin myös kulttuurisen diskurssianalyysin viides työkalu, oleminen paikassa ja ympäristöissä, joka taustoittaa vuorovaikutustilanteita ja niissä tuotettuja merkityksiä. Vaikka identiteetin merkityksiä tuotetaan viestinnässä usein selväsanaisesti, kulttuurinen diskurssianalyysi ei pelkästään keskity puheessa ilmeneviin eksplisiittisiin merkityksiin, vaan pyrkii analysoimaan ja tulkitse- maan myös niistä heijastuvia ja säteileviä piiloisempia merkityksiä kussakin puheyhteisössä ja sosiokulttuurisessa kontekstissa. Tutkimukseni näkökulmasta haasteellista ja toisaalta mielenkiintoista tässä analyysimenetelmässä on ollut se, etteivät kansainväliset työpaikat muodosta yhtenäistä puhe- tai kieliyhteisöä vaan hyvin monimuotoisen ja muutoksessa olevan työ- tai käytäntöyhteisön.

Positiointiteorian mukaan identiteetit rakentuvat ja muotoutuvat positioina, joita osallistujat antavat itselleen ja toisille vuorovaikutustilanteissa. Asemointia tapahtuu myös narratiiveissa, joissa yksilö kuvatessaan itseään tulee samalla kertoneeksi, mitä hän ei ole. Samoin lyhyissä, haastatteluihin sisältyvissä mikrotarinoissa puhujat voivat esittää ja positioida itseään suhteessa niihin, joille heidän tarinansa on suunnattu, olivatpa nämä fyysisesti paikalla, todellisia tai kuvitteellisia. Vuorovaikutuksessa positiointi voi ilmetä kolmella tasolla. Ensimmäisellä tasolla puhuja asemoi itseään tai toista suhteessa muihin. Toisen tason positioinnissa on kyse siitä, mitä aiemmasta asemoinnista seuraa tai miten siihen suhtaudutaan. Tarjottua identiteettipositiota voidaan vastustaa avoimesti, siitä voidaan neuvotella tai annettu asema voidaan hyväksyä sellaisenaan. Kolmannen tason positioinnissa on kyse selonteosta, jonka puhuja antaa tapahtumille myöhemmin välittömän vuorovaikutustilanteen ulkopuolella. Positiointianalyysin kautta työidentiteetin rakentumista on tässä tutkimuksessa voitu tarkastella myös organisatoristen roolien, oikeuksien ja velvollisuuksien ja valtarakenteiden näkökulmista.

\section{Keskeisimmät tulokset}

Mitä tutkimuksessa sitten löydettiin? BBA-tutkinnon suorittaneiden nuorten ammattilaisten työidentiteetti on äärimmäisen moniulotteinen, 
dynaaminen ja tilanteinen. Itseen kohdistuvia pysyviä, prototyyppisiä sosiaalisia identiteettejä vastustettiin silloin, kun niihin liitettiin negatiivisia ja toiseuttavia piirteitä. Toisaalta diskurssit tuottivat niin sanotun sulautuneen kansainvälisen hybridi-identiteetin, johon samaistuttiin muun muassa siksi, että se liitettiin avoimuuteen, arvokkaisiin ulkomaankokemuksiin ja viestinnän helppouteen yhteisen kielen, niin sanotun lingua franca englannin (ELF) avulla. Tutkimuksessa nousi esille myös kielen moninainen merkitys työidentiteetille, jota voi selittää muun muassa se, että kansainväliset työtehtävät edellyttävät monipuolista kielitaitoa ja kielestä tulee näin keskeinen osa kansainvälisen kaupan ammattilaisena olemista. Työpaikan kieli, kielet ja kielenkäytön tavat ovat niitä resursseja, joilla identiteetistä neuvotellaan ja joilla positioitaan itseä ja toista, otetaan mukaan tai eristetään, luodaan yhteenkuuluvuutta tai kuulumattomuutta. Vuorovaikutussuhteiden mikrotasolla esiintyvien jännitteiden ja organisaation sisällä käytävien diskursiivisten kamppailujen kautta pyrittiin kussakin tilanteessa optimaaliseen tasapainoon kuulumisen ja erottautumisen välillä.

Tutkimuksessa tarkastelin myös organisatorisiin rooleihin perustuvaa työidentiteettiä. Havaitsin, että vuorovaikutuksessa tapahtuvaa positiointia esiintyi enemmän vertaissuhteissa kuin esihenkilö-työntekijäsuhteissa. Esihenkilön organisatorista asemaa ei suoraan haastettu edes silloin, kun hänen koettiin toimivan rooliodotusten vastaisesti. Sen sijaan kahdessa haastattelussa todettiin, että "päivän päätteeksi pomo on pomo". Voidaankin olettaa, että kansainvälisten yritysten ja niiden toimintaympäristöjen nopea muutostahti ja työn epävarmuus saa nuoret työntekijät turvaamaan työsuhteidensa jatkumisen sillä, että he pysyttäytyvät heille tarjotussa roolissa ja positiossa. Myös vertaissuhteissa positiointi oli harvoin suoraa tai eksplisiittistä. Usein se piiloutui toiseuttavaan tai samaistavaan huumoriin, kömpelöihin kohteliaisuuksiin tai sanattomaan viestintään. Kolmannen asteen positiointi tuotti kuitenkin paikallisesti selkeitä rajanvetoja sukupuolittuneiden ammattiryhmien, miesinsinöörien ja kaupallisen koulutuksen saaneiden naisten välille teknologia-alan yrityksissä.

Työidentiteetti- ja muutosdiskurssi synnyttivät risteytyessään merkityksiä, joissa nuoret ammattilaiset näyttäytyivät aktiivisina toimijoina ja itsenäisinä omien, joskus epätavallisten urapolkujen rakentajina. Toisaalta 'job hopper' eli työpaikan vaihtajan muutostarinat heijastelivat ammatillisten kasvojen menettämisen pelkoa suhteessa perinteisiin nousujohteisiin uriin. Identiteettidiskurssissa rakentuvan 'jonglöörin' (engl. juggler) rajat työn ja muun elämän välillä olivat läpäiseviä ja muuttuvia, kun taas toisaalta 'eristyneen työntekijän' diskurssi tuotti selvärajaisimman eron yksityisen ja työelämän alueiden välille. Eristynyt työntekijä identifioitui organisaatioon selvemmin oman roolinsa ja työtehtäviensä kuin työpaikan vuorovaikutussuhteiden kautta. Työpaikalla tapahtuvan viestinnän perusteella voidaankin todeta, etteivät kansainvälisissä yrityksissä työskentelevät BBA-tradenomit näytä muodostavan yhtenäistä työntekijäryhmää, vaan heidän työidentiteettinsä ja identiteettipositionsa rakentuvat ja muotoutuvat jatkuvasti työhön liittyvissä ja työn ulkopuolisissa vuorovaikutussuhteissa sekä laajemmissa organisatorisissa ja yhteiskunnallisissa diskursseissa.

\section{Pohdintaa ja päätelmiä}

Työhön liittyvä identiteetti näyttää rakentuvan vuorovaikutuksessa dialektisten jännitteiden kautta, joita tämän tutkimuksen tulosten mukaan olivat muun muassa samaistumisen ja 
erottautumisen ja kuulumisen ja kuulumattomuuden jänniteparit. Toisaalta nämä myös punoutuivat laajempiin diskursseihin polarisaatiosta ja ammatti- tai kansanryhmien välisistä eroista ja toisaalta keskusteluun kansainvälisestä toimintaympäristöstä, jossa kulttuuriset, etniskielelliset, koulutukselliset, ammatilliset tai sukupuoleen liittyvät piirteet sulautuvat ja menettävät merkityksensä. Viestintää yhteiskunnan mikro-, meso- tai makrotasoilla ei siis voida selvärajaisesti erottaa, mikä tekee myös diskursiivisesti rakentuvasta työidentiteetistä monikerroksista ja dynaamista.

Sosiaalisessa vuorovaikutuksessa risteävät ja eritasoiset diskurssit nivoutuvat yhteen ja muodostavat ajoittain myös sotkuisia vyyhtejä, joita voi olla hankala selvittää. Solmukohdat ja risteymät ovat kuitenkin niitä kohtia, joita pitää tutkimuksellisesti purkaa auki, jotta voidaan ymmärtää kahdenvälisten vuorovaikutussuhteiden, monialaisten tiimien tai ylikansallisten yritysten dynamiikkaa, siis ihmistä sosiaalisena toimijana kansainvälisen työn konteksteissa. Työelämässä tapahtuvien muutosten keskiössä eivät ole ainoastaan robotit, tekoäly, kvanttilaskenta ja erilaiset teknologiset ratkaisut. Työn murroksen keskiössä ovat myös työtä tekevät ihmiset ja se, miten uusi työ ja työidentiteetit rakentuvat tiedon, viestinnän ja sosiaalisen vuorovaikutuksen kautta erilaisista taustoista tulevien yksilöiden välillä. Tulevaisuuden työtä ja työhön liittyviä identiteettejä onkin aiheellista tutkia tästä näkökulmasta myös jatkossa.
Miten tutkimukseni sitten palvelee kieli- ja viestintäopintojen kehittämistä ammattikorkeakoulussa? Viestintä ja vuorovaikutus ovat läsnä kaikilla inhimillisen toiminnan tasoilla ja rakentavat niin yksilöä, sosiaalisia suhteita, yhteisöjä, organisaatioita kuin yhteiskuntiakin. Työelämän muutos edellyttää joustavuutta ja laaja-alaista ja monipuolista viestintä- ja vuorovaikutusosaamista, joita ei voida kehittää erillään muusta asiantuntijuudesta. Tarvitaan suunnitelmallista eri aihealueita, sisältöjä, toteutustapoja, opintojaksoja ja todennäköisesti myös eri kieliä ja koulutusaloja integroivaa opetusta.

Koulutuksessa tarvitaan lisäksi syvällisempää ymmärrystä siitä, mitä kieli- ja viestintätaito mahdollistaa ja mitä se rajaa pois. Kulttuurienvälisen viestinnän opetuksessa on syytä keskittyä vuorovaikutusosaamiseen, joka lähtee yksilön kyvystä tarkkailla ja reflektoida omaa ja toisten toimintaan erilaisissa viestintätilanteissa ja ympäristöissä. Tähän olennaisena osana liittyy myös kriittinen ajattelu, jossa vuorovaikutusta analysoidaan tilanteisena siihen kytkeytyvien yksilöllisten arvojen ja asenteiden, yhteisöissä vallitsevien vallan rakenteiden sekä laajempien ideologioiden rajapinnoilla. Eikö tämä, jos mikä, ole korkeakoulutuksen sivistyksellinen tehtävä myös tulevaisuudessa?

\section{TITLE AND KEYWORDS IN ENGLISH:}

\section{The work identities of young business professionals are constructed in interaction}

KEYWORDS: discourse, international business, interpersonal communication, positioning, work identity 